\title{
Auditor's Perception on Technology Transformation: Blockchain and CAATs on Audit Quality in Indonesia
}

\author{
Meiryani $^{1}$, Monika Sujanto ${ }^{2}$, ASL Lindawati ${ }^{3}$, Arif Zulkarnain ${ }^{4}$, Suryadiputra Liawatimena ${ }^{5}$ \\ Accounting Department, Faculty of Economics and Communication, Bina Nusantara University, Jakarta, 11480 Indonesia $^{1,2,3}$ \\ Hotel Management Department, Faculty of Economics and Communication Bina Nusantara University, Jakarta, 11480 Indonesia $^{4}$ \\ Computer Science Department, BINUS Graduate Program - Master of Computer Science, Bina Nusantara University ${ }^{5}$
}

\begin{abstract}
The purpose of this study is to analyze the auditor's perception of the implementation of technology transformation such as: blockchain and CAATs that can affect audit quality at the Big Four Public Accounting Firm in Jakarta. This study uses quantitative research methods using a combination of primary and secondary data. The data collection techniques used in this study was questionnaires. The sample was taken using purposive sampling method, which resulted in 60 respondents. Data analysis was carried out with SmartPLS 3.0 and IBM SPSS 26 software which resulted in the conclusion that the auditor's perception of the implementation of blockchain had a significant positive effect on audit quality, while the auditor's perception of the implementation of CAATs had no significant positive effect on audit quality.
\end{abstract}

Keywords-Blockchain; CAATs; audit quality; auditor's perception; technology transformation

\section{INTRODUCTION}

The technological revolution and new business models emphasize the rapid use of technology. Technology has changed audit data processing and data storage from manual to automated. The role of auditors is increasingly important when digitalization in business processes is increasingly dominant [8]. The development of information technology in the company is not in line with changes in information technology-based auditing practices. This statement is supported by a World Bank report which states that auditors in Indonesia tend to use simple procedures to detect fraud and provide opinions on "going concern" assumptions. In this case, there is no rigorous process and it is a challenge to provide an accurate audit opinion as stakeholders feel they do not have sufficient information. This leads to questionable audit quality. To address audit quality issues, it is necessary to apply best audit practices by leveraging technological transformations in the audit process such as the use of blockchain and CAATs. The facts on the ground show that there are many problems related to audit quality, such as: SNP Finance, PT Hanson International Tbk, Indosat Ooredo, Garuda Indonesia, PT KAI (Indonesian Railways).

KAP really needs to solve the problem of high audit fees, low efficiency and high audit risk. It seems that blockchain is becoming the next step in the digital era and is expected to have an impact on business and society and attract the attention of scholars and practitioners [16]. In addition to blockchain, CAATs are one of the technological transformations in the field of auditing. CAATs can support auditors in collecting big data as audit evidence and analyzing it in a single database. The more data that is used as evidence, the less likely there is to be fraud or fraud. Although the cost of implementing CAATs is high, it reduces the work cost of the company's entire audit activity by increasing productivity and reducing the number of errors in the audit process. CAATs can help auditors provide the best service for their clients $[15,22]$. New discoveries such as big data and other similar technological advances have greatly increased the opportunities to improve current audit quality and practice. Due to audit limitations and lack of time, the auditor is forced to choose a smaller sample size, which can also lead to possible risk assessment and inadequate audit procedures. The contribution of this research is to determine audit quality through auditors' perceptions of technological transformation in the form of Blockchain and CAATs in public accounting firms in Indonesia.

\section{THEORETICAL FRAMEWORK}

\section{A. Agency Theory}

High audit quality can improve the quality of financial reports and support wise investment decisions and financial stability, but can also be used as a monitoring mechanism to reduce asymmetric information between managers and shareholders $[5,20]$. Audit quality can help companies obtain credit from the most prestigious creditors and attract potential investors to invest $[17,21]$. Audit quality plays an important role in increasing public confidence in the capital market by providing better information and confidence in the reliability and accountability of financial reports reported by management.

Agency theory can be defined as the relationship between the owner (principal) and management (agent), where the principal authorizes the agent to manage the company. If the principal and agent have the same goal, the agent will act in accordance with the wishes of the principal, agency problems arise when there are differences in the objectives of the principal and agent which gives rise to asymmetric information which is the difference in information between the principal and the agent, where the agent has more and more information than the principal because the agent spends more 
time in the company than the principal. The existence of asymmetric information can open up opportunities for agents to take inappropriate actions, which can harm the principal or the company by using company assets for personal gain. The task of the auditor is to provide services to assess the financial statements made by the agent regarding the fairness of the financial statements, so that the auditor is considered an independent party who can help overcome agency problems. In assessing the company's financial statements, the auditor must carry out the audit process optimally to obtain good audit quality.

Blockchain makes audit work easier but still has some problems to solve. To maintain audit quality, auditors must consider and assess blockchain risks in audits, such as: ID theft, illegal activity, and system hacking [9]. Information technology, audit techniques, and time budget pressure have a positive (+) effect on audit quality [13]. Private blockchains are attractive because they offer better audit solutions, automated controls, data reliability, reduced audit fees and less human error, avoids manipulation and fraud, improves information integrity, but blockchain still needs a lot of development, such as design, flexibility, and cyber security [3]. CAATs have a positive (+) effect on IT Audits [2]. In the research, Cheng and Huang (2020) also did not have variables in their research with results showing that blockchain has enormous potential in auditing and accounting. Although research on blockchain auditing is still in its infancy, blockchain technology can very well solve the problems currently facing the audit industry. [4].

With the help of blockchain audits, large-scale and realtime automated audits can be implemented. While companies can improve their data security structures, regulators are expected to strengthen and enforce crime-related regulations [37\}. Blockchain had an effect on the audit process and auditors, especially in collecting evidence and conducting audits [18]. CAATs increase audit effectiveness and efficiency but CAATs need deeper study and auditors' consideration because it is difficult to master CAATs. Middle to lower KAPs are still not interested in using complex CAATs [15]. Auditors see a high performance expectancy from the use of CAATs [11]. Auditor independence, auditor experience, and application of Audit Techniques Computer Assisted has a positive (+) effect on the effectiveness of the investigative audit in detecting fraud [7]. Blockchain is able to improve financial reporting and audit processes because auditors can access data in real-time, obtain information in a consistent and repeatable format, obtain audit evidence directly and according to procedures and overcome risks, audit but still have to do a professional analysis [16].

\section{HYPOTHESIS DEVELOPMENT}

\section{A. Effect of Blockchain Implementation on Audit Quality}

Blockchain is a technology for recording, processing and storing financial transactions [10, 22]. Blockchain records transactions chronologically with the cryptographic hash referring to the hash of the previous block, when any changes are made, all other copies are updated at the same time so that if there is fraud it will be easier for auditors to detect. After reaching consensus, all nodes can access the same information, and a distributed global view of the chain ensures the availability of stored information so that there is high transparency, auditors can access all required transactions and can obtain sufficient and reliable evidence to determine whether there is a material misstatement. Blockchain implementation allows auditors to focus on data analysis and decision making rather than checking recurring transactions and ensuring that they meet accounting standards [4]. Blockchain can reduce audit fees, human error, and fraud [3]. Blockchain helps the audit process, especially in the collection of reliable and transparent audit evidence [18]. Blockchain implements a real-time system and large-scale automated audits, as well as guaranteed data security [19]. The hypotheses in this study are as follows.

H1: Blockchain implementation has a positive effect on audit quality.

\section{Effect of CAATs Implementation on Audit Quality}

CAATs are computerized programs to carry out audit functions so as to facilitate the audit process and also facilitate access and perform comprehensive operations on various types of electronic data so that fraud can be prevented early [2] thus affecting the quality of audits produced by auditors. Public accounting firms use software to help auditors complete their audit tasks with the help of computers so that auditors can carry out their duties properly and produce highquality audit reports. Implementation of CAATs and training to understand the use of CAATs tends to be expensive because auditors who will use CAATs need to have knowledge depending on the complexity of CAATs so there are considerations from several KAPs. CAATs have a positive (+) effect on the operational review of IT audits which consist of preaudit, implementation, and reporting [2]. Computer Assisted Audit Techniques [1], Auditor Competence, Independence, and Work Experience have a positive $(+)$ effect on audit quality [12]. CAATs increase audit effectiveness and efficiency but are difficult to implement, so there are still considerations from KAP [15]. The hypotheses in this study are as follows:

H2: The application of CAATs has a positive effect on audit quality.

\section{RESEARCH METHODOLOGY}

This research was conducted by focusing on the Big Four KAP operating in Jakarta, Indonesia. The sample in this study were auditors at KAP Big Four Jakarta. Indonesia who have knowledge related to research topics and are interested in participating in this research. In this study, the author uses quantitative research methods, which can be interpreted as research that uses data in the form of numbers from calculations and measurements that are processed and analyzed with certain statistical criteria. Quantitative research is more likely to be used to prove phenomena (hypotheses) $[12,21]$.

In this study, information was collected from respondents using a questionnaire. Due to the large population, the authors collect data using a sampling technique, namely purposive sampling. The results of the selected sample will represent the entire population. The number of population is unknown, so 
the Roscoe formula is used, namely the sample size in multiple regression analysis is at least 10x larger than the number of variables in the study and must be more than 30 and less than 500 samples [6]. The sample was selected using the following criteria: Auditor has worked at KAP Big Four for at least 1 year; Auditors have knowledge and understanding of blockchain, CAATs, and audit quality; Auditors have an interest in participating in research.

The sample members are selected based on criteria, such as people who already have proven knowledge, experience, and skills in the field being researched. The number of samples used as respondents as many as 60 samples. The results of data analysis in this study consisted of respondent characteristics, descriptive statistical analysis, normality test, multicollinearity test, heteroscedasticity test, autocorrelation test, validity test, and reliability test; the results of hypothesis testing consisting of the coefficient of determination $\left(R^{2}\right)$, fsquare (effect size), path coefficient, T-Statistics test (bootstrapping), predictive relevance (Q2), and model fit; discussion of research results [14, 20].

Operational variable

Blockchain Application (X1) measured by indicator: (1) knowledge and skills of auditors related to blockchain; (2) Availability of support for blockchain implementation in the audit process; (3) Effectiveness in implementing blockchain; (4) Efficiency in blockchain implementation. Application of CAATs (X2) by using indicators; (1) Knowledge and skills of auditors related to CAATs; (2) Effectiveness in implementing CAATs.(3). Efficiency in the application of CAATs. Audit Quality (Y) with indicator measurement: (1) Professional knowledge, expertise and experience; (2) Misstatement detection; (3) Compliance with auditing standards; (4) Quality of audit report.

\section{RESUlt AND DISCUSSION}

\section{A. Descriptive Statistical Analysis}

The Table I shows descriptive statistical analysis of the mean value of Exogenous Variables (Blockchain Application) of 38.90; the mean value of Exogenous Variables (Application of CAATs) is 41.25; the mean value of Endogenous Variables (Audit Quality) is 63.68. The standard deviation value for Exogenous Variables (Blockchain Application) is 6.501; the standard deviation value of Exogenous Variables (Application of CAATs) is 6.022; the standard deviation value of Endogenous Variables (Audit Quality) is 4,489.

TABLE I. DESCRIPTIVE STATISTICAL ANALYSis

\begin{tabular}{|l|l|l|}
\hline Variable & Mean & Standard Deviation \\
\hline Exogenous (Blockchain Implementation) & 38,90 & 6,501 \\
\hline Exogenous (Application of CAATs) & 41,25 & 6,022 \\
\hline Endogenous (Quality Audit) & 63,68 & 4,489 \\
\hline \multicolumn{2}{|c|}{ Source: Processed data (2021) }
\end{tabular}

\section{B. Normality Test}

The absolute value is the statistical value of the Kolmogorov-Smirnov test, while the significance value of Asymp. Sig. (2-tailed) is the probability value of the
Kolmogorov-Smirnov test. By using 60 samples and a significance level of 0.05 , the Kolmogorov-Smirnov critical value is 0.172 . Judging from the Table II, the absolute value is $0.073<0.172$ and the Asymp value. Sig. (2-tailed) of $0.20>$ 0.05 . So, the data in this study are normally distributed.

TABLE II. NORMALITY TEST

\begin{tabular}{|l|l|l|}
\hline \multicolumn{2}{|l|}{ One-Sample Kolmogorov-Smirnov Test } \\
\hline \multicolumn{2}{|l|}{ N } & Unstandardized Residual \\
\hline \multirow{2}{*}{ Normal Parameters ${ }^{\text {a,b }}$} & Mean & .0000000 \\
\cline { 2 - 3 } & Std. Deviation & 4.01092676 \\
\hline \multirow{4}{*}{ Most Extreme Differences } & Absolute & .073 \\
\cline { 2 - 3 } & Positive & .073 \\
\cline { 2 - 3 } & Negative & -.072 \\
\hline Test Statistic & .073 \\
\hline Asymp. Sig. (2-tailed) & $.200^{\text {c,d }}$ \\
\hline a. Test distribution is Normal. \\
\hline b. Calculated from data. \\
\hline c. Lilliefors Significance Correction. \\
\hline d. This is a lower bound of the true significance. \\
\hline
\end{tabular}

Source: IBM SPSS 26 output, processed data (2021)

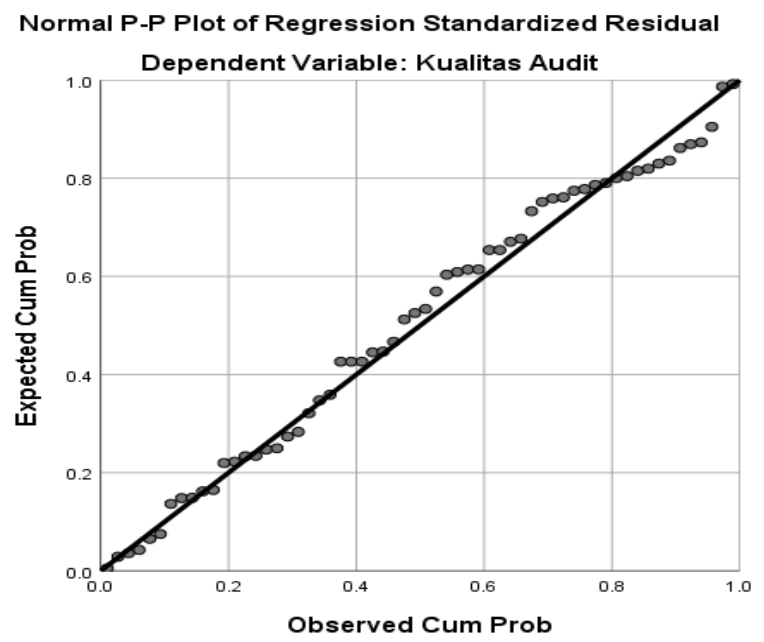

Source: IBM SPSS 26 output, processed data (2021).

Fig. 1. Probability Plot Normality Test.

Seen in the Fig. 1, the dots spread around the diagonal line and follow the diagonal line. This shows that the data is normally distributed. The P-P Plot of Regression Normal Test can be done if you are still unsure of the KolmogorovSmirnov test results.

\section{Multi-collinearity Test}

Based on the Table III, it can be seen that the value of Exogenous Variables (Blockchain Application) and Exogenous Variables (CAATs Application) value is the same, namely 1.208 which means that the two exogenous variables in this study have a VIF value $<10$. This means that there is no multi-collinearity in this study. 
TABLE III. MULTI-COLlineARity Test

\begin{tabular}{|l|c|l|}
\hline & VIF & Information \\
\hline $\begin{array}{l}\text { Exogenous Variables (Blockchain } \\
\text { Implementation) }\end{array}$ & 1,208 & $\begin{array}{l}\text { There is no multi- } \\
\text { collinearity }\end{array}$ \\
\hline $\begin{array}{l}\text { Exogenous Variables (Application of } \\
\text { CAATs) }\end{array}$ & 1,208 & $\begin{array}{l}\text { There is no multi- } \\
\text { collinearity }\end{array}$ \\
\hline
\end{tabular}

Source: Output SmartPLS 3.3.3, Data processed (2021)

\section{Heteroscedasticity Test}

The Park test was carried out by looking at the scatterplot using SRESID as the $\mathrm{Y}$ variable and ZPRED as the $\mathrm{X}$ variable. It can be seen from the Fig. 2 below that there is a random distribution of points in the residual analysis around 0 , the spread the points are far from the $\mathrm{X}$ and $\mathrm{Y}$ axes. So, it can be concluded that there is no heteroscedasticity.

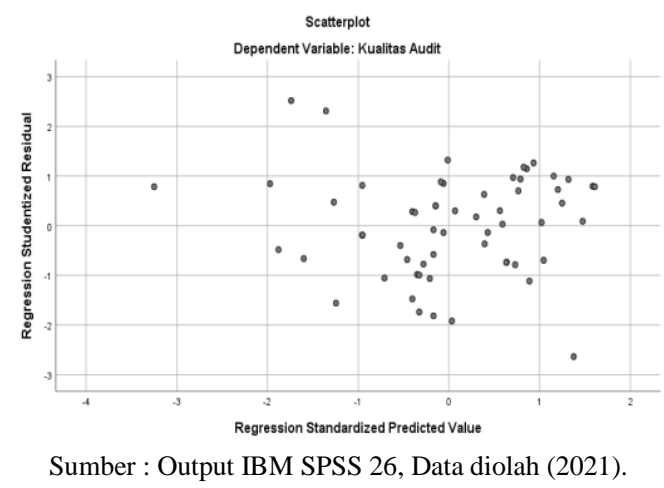

Fig. 2. Heteroscedasticity Test.

\section{E. Autocorrelation Test}

The Table IV shows Durbin Watson's result of 2,061. By using 60 samples, obtained a dL value of 1.5144 and a dU value of 1.6518 from the Durbin Watson table. If $1.65<\mathrm{d}<$ 2.35 , it means that there is no autocorrelation, if $1.51<\mathrm{d}<$ 1.65 or $2.35<\mathrm{d}<2.49$, it means that it cannot be concluded, if $\mathrm{d}<1.51$ or $\mathrm{d}>2.49$ means that there is an autocorrelation. Judging from the statement obtained the results: $1.65<2.06<$ 2.35 , it can be concluded that there is no autocorrelation in this study.

TABLE IV. AUtOCORRELATION TEST

\begin{tabular}{|l|l|l|l|l|l|}
\hline $\mathbf{n}$ & Durbin Watson & dL & dU & 4-dL & 4-dU \\
\hline 60 & 2,061 & 1,5144 & 1,6518 & 2,4856 & 2,3482 \\
\hline \multicolumn{5}{|c|}{ Source: IBM SPSS 26 output, processed data (2021) }
\end{tabular}

\section{F. Validity Test}

The following measurement model is used to analyze the questionnaire:

Based on the Fig. 3 of the loading factor analysis of SmartPLS 3.3.3, it can be seen that many indicators have a value below 0.6 , namely: $\mathrm{BC} 2$ with a value of 0.427 ; $\mathrm{BC} 3$ with a value of 0.360 ; BC4 with a value of 0.387 ; CA2 with a value of 0.583 ; KA1 with a value of 0.576 ; KA2 with a value of 0.515 ; KA3 with a value of 0.478 ; KA4 with a value of 0.401 ; KA5 with a value of 0.525 ; KA6 with a value of 0.591 ; KA7 with a value of 0.503 ; KA8 with a value of 0.565 ; KA10 with a value of 0.592 ; and KA14 with a value of 0.550 .
Indicators with values below 0.6 are invalid and must be removed from the model. If the indicator used is not valid then it cannot measure each variable, the value given by the exogenous variable to the endogenous variable cannot be used as a guide.

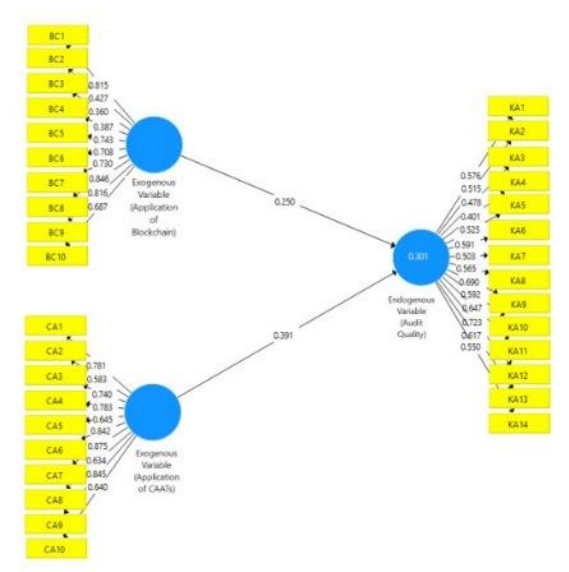

Fig. 3. Estimated Measurement Model.

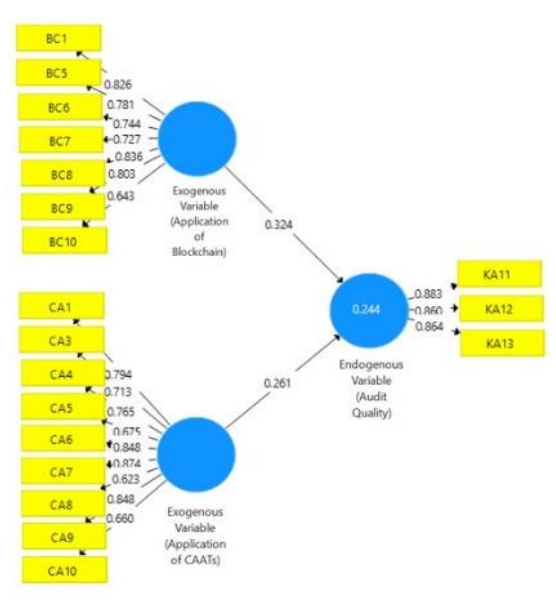

Fig. 4. Valid Model Estimation.

From the model estimation Fig. 4, it can be seen that after all indicators have a loading factor value above 0.6 so that the model meets the requirements of convergent validity. All indicators used are valid, namely: $\mathrm{BC} 1$ with a value of 0.826 ; BC5 with a value of 0.781 ; BC6 with a value of 0.744 ; BC7 with a value of 0.727 ; $\mathrm{BC} 8$ with a value of 0.836 ; $\mathrm{BC} 9$ with a value of 0.803 ; $\mathrm{BC} 10$ with a value of 0.643 ; $\mathrm{CA} 1$ with a value of 0.794 ; CA3 with a value of 0.713 ; CA4 with a value of 0.765 ; CA6 with a value of 0.848 ; CA7 with a value of 0.874 ; CA8 with a value of 0.623 ; CA9 with a value of 0.848 ; CA10 with a value of 0.660 ; KA11 with a value of 0.883 ; KA12 with a value of 0.860 ; and KA13 with a value of 0.864 .

1) Convergent validity test: The convergent validity test can be seen by looking at the value of outer loadings in the PLS Algorithm. Each indicator with a value $>0.6$ has been declared valid. If there is still a value $<0.6$, then you must return to the estimation model and delete indicators that have a value $<0.6$. The Table $\mathrm{V}$ shows a comparison of the value of outer loadings before being deleted and after being deleted 2 
times. After deleting the value at $<0.6$, the value of KA9 changed from 0.690 to $<0.6$ i.e. 0.537 ; so it must be deleted again before doing the next test.

TABLE V. OUTER LOADINGS

\begin{tabular}{|c|c|c|}
\hline Indicator & $\begin{array}{l}\text { Outer Loadings Before } \\
\text { Deletion }\end{array}$ & $\begin{array}{l}\text { Outer Loadings After } \\
\text { Deletion }\end{array}$ \\
\hline $\mathrm{BC} 1$ & 0,815 & 0,826 \\
\hline $\mathrm{BC} 2$ & 0,427 & - \\
\hline $\mathrm{BC} 3$ & 0,360 & - \\
\hline $\mathrm{BC} 4$ & 0,387 & - \\
\hline $\mathrm{BC} 5$ & 0,743 & 0,781 \\
\hline BC6 & 0,708 & 0,744 \\
\hline BC7 & 0,730 & 0,727 \\
\hline BC 8 & 0,846 & 0,836 \\
\hline BC9 & 0,816 & 0,803 \\
\hline $\mathrm{BC} 10$ & 0,687 & 0,643 \\
\hline CA1 & 0,781 & 0,794 \\
\hline $\mathrm{CA} 2$ & 0,583 & - \\
\hline CA3 & 0,740 & 0,713 \\
\hline CA4 & 0,783 & 0,765 \\
\hline CA5 & 0,645 & 0,675 \\
\hline CA6 & 0,842 & 0,848 \\
\hline CA7 & 0,875 & 0,874 \\
\hline CA8 & 0,634 & 0,623 \\
\hline CA9 & 0,845 & 0,848 \\
\hline CA10 & 0,640 & 0,660 \\
\hline KA1 & 0,576 & - \\
\hline KA2 & 0,515 & - \\
\hline KA3 & 0,478 & - \\
\hline KA4 & 0,401 & - \\
\hline KA5 & 0,525 & - \\
\hline KA6 & 0,591 & - \\
\hline KA7 & 0,503 & - \\
\hline KA8 & 0,565 & - \\
\hline KA9 & 0,537 & - \\
\hline KA10 & 0,592 & - \\
\hline KA11 & 0,647 & 0,883 \\
\hline KA12 & 0,723 & 0,860 \\
\hline KA13 & 0,617 & 0,864 \\
\hline KA14 & 0,550 & - \\
\hline
\end{tabular}

Source: Output SmartPLS 3.3.3, Data processed (2021)
TABLE VI. AVERAge VARIANT EXTRACTED (AVE)

\begin{tabular}{|l|l|l|}
\hline Variable & $\begin{array}{l}\text { Average Variant } \\
\text { Extracted (AVE) }\end{array}$ & Information \\
\hline $\begin{array}{l}\text { Exogenous (Blockchain } \\
\text { Implementation) }\end{array}$ & 0,590 & Valid \\
\hline Exogenous (Application of CAATs) & 0,578 & Valid \\
\hline Endogenous (Quality Audit) & 0,756 & Valid \\
\hline
\end{tabular}

Source: Output SmartPLS 3.3.3, Data processed (2021)

In addition to using the loading factor, the convergent validity test is also seen from the AVE value from Table VI. The AVE value can be seen by selecting construct reliability and validity. The AVE value is used to ensure that there are still invalid indicators after the loading factor test. An AVE value $>0.5$ indicates that the AVE value is valid and an AVE value $<0.5$ indicates that there are still invalid indicators. The three variables have a value $>0.5$, which means that all variables are valid.

2) Discriminant validity test: Table VII shows the first discriminant validity test is by using the Fornell-Larcker Criterion by looking at the correlation of the variable with the variable itself, it must not be smaller than the variable with other variables. If the correlation of the variable with the variable itself is smaller than the variable with other variables, it must remove the lowest indicator value from that variable because the correlation value generated by loading factors results in a lack of the Fornell-Larcker Criterion test. In this study, the correlation between the variables and the variables themselves is greater than the variables with other variables.

Table VIII shows the second discriminant validity test is by using cross loadings. Cross loadings can be seen by comparing the correlation of indicators with their own variables, whether it is greater than the correlation of indicators with other variables. When there is an indicator correlation with other variables that is greater than the indicator correlation with its own variable, it must be removed. Because everything is valid, both the convergent and discriminant validity tests, the indicators that are owned can be used as a measure of the variables used.

\section{G. Reliability Test}

Reliability test using Cronbach's alpha can be seen by selecting construct reliability and validity from Table IX. The value of Cronbach's alpha in this study can be seen in the table above, which means that each variable used is all reliable because the Cronbach's Alpha value of each variable is >0.6. Same as the previous test, if it displays red, it means it is not reliable. 
TABLE VII. FORNELL-LARCKER CRITERION

\begin{tabular}{|l|l|l|l|}
\hline & $\begin{array}{l}\text { Exogenous Variables } \\
\text { (Blockchain Implementation) }\end{array}$ & $\begin{array}{l}\text { Exogenous Variables } \\
\text { (Application of CAATs) }\end{array}$ & $\begin{array}{l}\text { Endogenous Variables } \\
\text { (Audit Quality) }\end{array}$ \\
\hline Exogenous Variables (Blockchain Implementation) & 0,768 & & \\
\hline Exogenous Variables (Application of CAATs) & 0,415 & 0,761 & \\
\hline Endogenous Variables (Audit Quality) & 0,433 & 0,396 & 0,869 \\
\hline
\end{tabular}

TABLE VIII. CROSS LOADINGS

\begin{tabular}{|l|l|l|l|}
\hline & $\begin{array}{l}\text { Exogenous Variables } \\
\text { (Blockchain } \\
\text { Implementation) }\end{array}$ & $\begin{array}{l}\text { Exogenous } \\
\text { Variables } \\
\text { (Application of } \\
\text { CAATs) }\end{array}$ & $\begin{array}{l}\text { Endogenous } \\
\text { Variables } \\
\text { (Audit Quality) }\end{array}$ \\
\hline BC1 & 0,826 & 0,372 & 0,470 \\
\hline BC5 & 0,781 & 0,240 & 0,335 \\
\hline BC6 & 0,744 & 0,275 & 0,209 \\
\hline BC7 & 0,727 & 0,392 & 0,149 \\
\hline BC8 & 0,836 & 0,338 & 0,318 \\
\hline BC9 & 0,803 & 0,358 & 0,413 \\
\hline BC10 & 0,643 & 0,278 & 0,090 \\
\hline CA1 & 0,372 & 0,794 & 0,356 \\
\hline CA3 & 0,323 & 0,713 & 0,313 \\
\hline CA4 & 0,213 & 0,765 & 0,173 \\
\hline CA5 & 0,323 & 0,675 & 0,288 \\
\hline CA6 & 0,371 & 0,848 & 0,310 \\
\hline CA7 & 0,345 & 0,874 & 0,287 \\
\hline CA8 & 0,298 & 0,623 & 0,219 \\
\hline CA9 & 0,353 & 0,848 & 0,367 \\
\hline CA10 & 0,182 & 0,660 & 0,299 \\
\hline KA11 & 0,445 & 0,328 & 0,883 \\
\hline KA12 & 0,369 & 0,404 & 0,860 \\
\hline KA13 & 0,292 & 0,287 & 0,864 \\
\hline & & $50 u r c:$ Output SmartPLS 3.3 .3$, Data processed (2021) \\
\hline
\end{tabular}

TABLE IX. CRONBACH'S ALPHA

\begin{tabular}{|l|l|l|}
\hline Variable & Cronbach's Alpha & Information \\
\hline $\begin{array}{l}\text { Exogenous (Blockchain } \\
\text { Implementation) }\end{array}$ & 0,895 & Reliable \\
\hline Exogenous (Application of CAATs) & 0,907 & Reliable \\
\hline Endogenous (Quality Audit) & 0,840 & Reliable \\
\hline
\end{tabular}

TABLE X. COMPOSITE RELIABILITY

\begin{tabular}{|l|l|l|}
\hline Variable & $\begin{array}{l}\text { Composite } \\
\text { Reliability }\end{array}$ & Information \\
\hline $\begin{array}{l}\text { Exogenous (Blockchain } \\
\text { Implementation) }\end{array}$ & 0,909 & Reliable \\
\hline Exogenous (Application of CAATs) & 0,924 & Reliable \\
\hline Endogenous (Quality Audit) & 0,903 & Reliable \\
\hline \multicolumn{2}{|c|}{ Source: Output SmartPLS 3.3.3, Data processed (2021) }
\end{tabular}

The second reliability test is by using composite reliability which can be seen by selecting construct reliability and validity that can be seen in Table X. The composite reliability value must be $>0.7$ to be said to be reliable. It can be seen in the table above that all variables are reliable because the composite reliability value is $>0.7$.

\section{H. Hypothesis Testing Results}

From Table XI, the value of 0.244 is only for endogenous variables. If used as a percent, the $\mathrm{R}$ Square value becomes $24 \%$, which means that only $24 \%$ of Exogenous Variables (Audit Quality) are influenced by Endogenous Variables (Blockchain Implementation) and Endogenous Variables (CAATs Application). The remaining $76 \%$ is influenced by other variables that are not used in the study.

The value of R Square Adjusted from this research is $22 \%$. $\mathrm{R}$ Square Adjusted to overcome the problem of increasing the value of $\mathrm{R}$ Square every time there is an additional variable because R Square Adjusted only measures R Square with a significant value. In addition, it can also be used to estimate the value of $\mathrm{R}$ Square from the addition of these variables. Because this study only uses 2 exogenous variables, it is enough to use the $\mathrm{R}$ Square value. $\mathrm{R}$ Square Adjusted value is more recommended for research that uses many exogenous variables/complex model.

From the Table XII, it can be seen that Exogenous Variables (Blockchain Implementation) have a weak influence on Endogenous Variables (Audit Quality) with a value of 0.115 and Exogenous Variables (Implementation of CAATs) also have a weak influence on Endogenous Variables (Audit Quality) with a value of 0.075 . The two exogenous variables have a weak influence because the f-Square values are both < 0.15 .

Path coefficient value can be seen by selecting the path coefficient. From the Table XIII, it can be seen that Exogenous Variables (Blockchain Implementation) to Endogenous Variables (Audit Quality) have a value of 0.324 and Exogenous Variables (Implementation of CAATs) to Endogenous Variables (Audit Quality) have a value of 0.261. Therefore, the direction of the relationship of Exogenous Variables (Blockchain) to Endogenous Variables (Audit Quality) and Exogenous Variables (CAATs) to Endogenous Variables (Audit Quality) is positive.

TABLE XI. COEFFICIENT OF DETERMINATION $\left(\mathrm{R}^{2}\right)$

\begin{tabular}{|l|l|l|l|}
\hline & $\begin{array}{l}\text { R } \\
\text { Square }\end{array}$ & $\begin{array}{l}\text { R Square } \\
\text { Adjusted }\end{array}$ & Model \\
\hline $\begin{array}{l}\text { Endogenous Variables (Audit } \\
\text { Quality) }\end{array}$ & 0,244 & 0,217 & Weak \\
\hline
\end{tabular}


TABLE XII. F-SQUARE

\begin{tabular}{|l|l|l|}
\hline & f-Square & Information \\
\hline $\begin{array}{l}\text { Exogenous Variables (Blockchain } \\
\text { Implementation) } \rightarrow \text { Endogenous Variables } \\
\text { (Audit Quality) }\end{array}$ & 0,115 & Weak \\
\hline $\begin{array}{l}\text { Exogenous Variables (Application of } \\
\text { CAATs) } \rightarrow \text { Endogenous Variables (Audit } \\
\text { Quality) }\end{array}$ & 0,075 & Weak \\
\hline
\end{tabular}

TABLE XIII. PATH COEFFICIENT

\begin{tabular}{|l|l|l|}
\hline Exogenous Variable & $\begin{array}{l}\text { Endogenous Variables (Audit } \\
\text { Quality) }\end{array}$ & $\begin{array}{l}\text { Relationship } \\
\text { Direction }\end{array}$ \\
\hline $\begin{array}{l}\text { Blockchain } \\
\text { Application } \\
\text { Application of CAATs }\end{array}$ & 0,324 & Positive \\
\hline & 0,261 & Positive \\
\hline
\end{tabular}

Source: Output SmartPLS 3.3.3, Data processed (2021).

The Table XIV shows that Exogenous Variables (Blockchain Application) have a significant effect on Endogenous Variables (Audit Quality) because the T-Statistics value is 2.203 and $\mathrm{p}$ value is 0.030 , while Exogenous Variables (Application of CAATs) have no significant effect on Endogenous Variables (Audit Quality) because the TStatistics value is 1.720 and the p value is 0.089 .

Predictive relevance can be seen by using blindfolding Construct Crossvalidated Redundancy. The results of Q2 in the Table XV show that the model used has a good observation value because it is already above 0 which is 0.152 .

Model Fit can be seen from the NFI value in Table XVI. In this study, the NFI value is 0.625 , which means that the model used in the study is $63 \%$ fit.

TABLE XIV. T-STATISTICS TEST

\begin{tabular}{|l|l|l|l|}
\hline & $\begin{array}{l}\text { T- } \\
\text { Statistics }\end{array}$ & $\begin{array}{l}\text { P } \\
\text { Values }\end{array}$ & Information \\
\hline $\begin{array}{l}\text { Exogenous Variables } \\
\text { (Blockchain Implementation) } \rightarrow \\
\text { Endogenous Variables (Audit } \\
\text { Quality) }\end{array}$ & 2,203 & 0,030 & Significant \\
\hline $\begin{array}{l}\text { Exogenous Variables } \\
\text { (Application of CAATs) } \rightarrow \\
\text { Endogenous Variables (Audit } \\
\text { Quality) }\end{array}$ & 1,720 & 0,089 & Not significant \\
\hline
\end{tabular}

Source: Output SmartPLS 3.3.3, Data processed (2021)

TABLE XV. Predictive ReleVance $\left(Q^{2}\right)$

\begin{tabular}{|l|l|l|}
\hline & $\mathbf{Q}^{\mathbf{2}}$ & Information \\
\hline $\begin{array}{l}\text { Endogenous Variables (Audit } \\
\text { Quality) }\end{array}$ & 0,152 & $\begin{array}{l}\text { Has predictive } \\
\text { relevance }\end{array}$ \\
\hline
\end{tabular}

TABLE XVI. TABLE XVI FIT MODEL

\begin{tabular}{|l|l|}
\hline NFI & $\mathbf{0 , 6 2 5}$ \\
\hline \multicolumn{2}{|c|}{ Source: Output SmartPLS 3.3.3, Data processed (2021) } \\
\hline
\end{tabular}

\section{DISCUSSION}

The Effect of Blockchain Implementation is on Audit Quality.

The test results show that the T-Statistics value is 2.203 and the $\mathrm{p}$ value is 0.030 ; path coefficients value of 0.324 . These results indicate that the implementation of Blockchain has a significant positive effect on audit quality. That is, the greater the level of Blockchain application in the audit process, the higher the audit quality. So, the first hypothesis, namely the implementation of Blockchain has a positive effect on audit quality, is acceptable.

Blockchain has many benefits that can be felt by auditors and KAP such as: data security; transparency and traceability; reduce fraud and manipulation; and reduce audit fees. Judging from the benefits of blockchain, with the development of blockchain, the intention of auditors to study blockchain, and the intention of KAP to facilitate resources in implementing blockchain in the audit process, blockchain can bring changes to the audit system. With the reduced intention to use blockchain in audits, it can be seen that the use of blockchain has no effect on audit quality.

The Effect of CAATs Implementation is on Audit Quality. The results of data processing show that the T-Statistics value is 1.720 and the $p$ value is 0.089 ; path coefficients value of 0.261 . These results indicate that the application of CAATs has no significant positive effect on audit quality. That is, the more CAATs are applied in the audit process, the more audit quality will not improve. So, the second hypothesis, namely the application of CAATs has a positive effect on audit quality, is rejected. The application of complex CAATs is quite difficult to learn. So without intention and understanding, CAATs cannot be applied and the benefits offered cannot be maximized because CAATs are only part of auditing standards to collect data and evaluate company transactions. Although in the audit process, CAATs can help auditors in the audit process to be more effective and efficient, such as: enabling the processing of thousands of transaction data, being able to check $100 \%$ of all transactions from the database, and CAATs being able to detect financial errors and fraud by checking data availability. The advantages of these CAATs can be utilized by auditors in order to improve audit quality only if the auditor has the desire to learn and use CAATs, and requires knowledge, experience, and skills from the auditors in conducting audits because CAATs are only tools. Judging from the results of the distributed questionnaires, it shows that knowledge and understanding related to computers and CAATs are needed by auditors.

\section{CONCLUSION}

Conclusion - From the phenomenon, problem formulation, hypothesis development, results and discussion of research, it can be concluded as follows:

1) The application of blockchain in the audit process has a positive effect on audit quality.

2) The application of CAATs has no positive effect on audit quality. 
Suggestions - From the results of this study, there are several suggestions, namely:

1) It is expected that auditors can learn and apply blockchain and CAATs in the audit process so as to improve audit quality. Auditors who have knowledge, understanding, and skills related to blockchain and complex CAATs will have more value and increase effectiveness and efficiency in the audit process.

2) It is hoped that the Big Four KAP in Jakarta Indonesia can implement and facilitate auditors in implementing blockchain and complex CAATs in auditing practices so as to improve audit.

\section{REFERENCES}

[1] Amerthajaya, N. T., \& Aryani M, N. K. (2016). Effect of Computer Assisted Audit Techniques, Due Professionalism Care, Accountability, Spiritual Intelligence on Audit Quality. Udayana University Accounting E-Journal, XVII(2), 1603-1634.

[2] Asniarti, \& Muda, I. (2019). The Effect of Computer Assisted Audit Tools on Operational Review of Information Technology Audits. Advances in Social Science, Education and Humanities Research (ASSEHR), CCVIII, 23-27.

[3] Bonson, E., \& Bednarova, M. (2019). Blockchain and Its Implications for Accounting and Auditing. emerald insight, XXVII(5), 725-740.

[4] Cheng , C., \& Huang, Q. (2020). Exploration on the Application of Blockchain Audit. Advances in Economics, Business, and Management Research , CX(12), 63-68.

[5] Ciger, A. (2020). Audit Quality: A Bibliometric Analysis (1981-2020). Scientific Annals of Economics and Business, LXVII(4), 473-494.

[6] Fatmawati, A., K, K. A., \& Wulandari, R. (2017). The Influence of Independence, Skepticism and Professional Ethics of Auditors on Audit Quality (Empirical Study on KAP in Malang City). Research Journal of Accounting Students, V(1), 1-19.

[7] Fauzi, M. R., Anwar, C., \& Ulupui, I. K. (2020). Influence of Independence, Experience, and Application of Computer Assisted Audit Techniques (TABK) on the Effectiveness of Investigative Audit Implementation in Detecting Fraud. Journal of Accounting, Taxation and Auditing, I(1), 1-15.

[8] Lestari, D., Mardian, S., \& Firman, M. A. (2020). Why Don't Auditors Use Computer-Assisted Audit Techniques? A Study at Small Public Accounting Firms. The Indonesian Accounting Review, X(2), 105-116.

[9] Li, Z. (2017). Will Blockchain Change the Audit? China-USA Business Review, XVI(6), 294-298.
[10] Liu, M., Wu, K., \& Xu, J. J. (2019). How Will Blockchain Technology Impact Auditing and Accounting: Permissionless versus Permissioned Blockchain. American Accounting Association Auditing, XIII(2), A19A29.

[11] Marei, D., \& Dr.Takiah, P. (2020). The impact of Computer Assisted Auditing Techniques (CAATs) on Development of Audit Process: an Assessment of Performance Expectancy of By The Auditors. International Journal of Management and Commerce Innovations, VII(2), 1199-1205.

[12] Muhayoca, R., \& Ariani, N. E. (2017). Pengaruh Teknik Audit Berbantuan Komputer, Kompetensi Auditor, Independensi, dan Pengalaman Kerja terhadap Kualitas Audit (Studi pada Auditor Bpk RI Perwakilan Provinsi Aceh). Jurnal Ilmiah Mahasiswa Ekonomi Akuntansi (JIMEKA), II(4), 31-40.

[13] Murfadila, \& Ramdani, M. R. (2019). Pengaruh Teknologi Informasi, Teknik Audit, Tekanan Anggaran Waktu Terhadap Kualitas Hasil Audit. AkMen Jurnal Ilmiah, XVI(1), 133-144.

[14] Sarwono, J., \& Narimawati, U. (2016). Membuat Skripsi, Tesis dan Disertasi dengan Partial Least Square SEM (PLS SEM). Yogyakarta: Andi.

[15] Serpeninova, Y., Makarenko, S., \& Litvinova, M. (2020). ComputerAssisted Audit Techniques : Classification and Implementation by Auditor. Public Policy and Accounting, I, 44-49.

[16] Simoes, M. P., Cavalcanti, J. A., Melo, J. F., \& Reis, C. Q. (2021). Benefits of Using Blockchain Technology As an Accounting Auditing Instrument. Ambiente Contabil, XIII(1), 40-53.

[17] Tandiontong, M. (2016). Kualitas Audit dan Pengukurannya. Bandung: Alfabeta.

[18] Usul, H., \& Karaburun, G. (2020). Changes in The Professional Profile of Auditors in The Light of Blockchain Technology. European Journal of Digital Economy Research, I(1), 5-12.

[19] Zhang, Y., Xiong, F., Xie, Y., Fan, X., \& Gu, H. (2020). The Impact of Artificial Intelligence and Blockchain on the Accounting Profession. IEEEAccess, VIII(10), 110461-110477.

[20] Azhar Susanto \& Meiryani. 2019. Antecedents of environmental management accounting and environmental performance : Evidence from Indonesian small and medium enterprises. International Journal of Energy Economics and Policy. 9(6), pp. 401-407.

[21] Meiryani and Azhar Susanto. 2018. The Influence of Information Technology on The Quality of Accounting Information System. ACM International Conference Proceeding Series. Pp.109-115.

[22] Winwin Yadiati \& Meiryani. 2019. The role of information technology in E-Commerce. International Journal of Scientific and Technology Research 8(1), pp. 148-150. 